\title{
Political party elite and election-related violence in Nigeria: The nexus and implications for democracy and governance
}

\author{
Ahmed Olawale Moliki ${ }^{{ }^{*}}$ \\ ${ }^{1}$ Department of Political Science, Tai Solarin University of Education, Nigeria \\ * Corresponding author \\ E-mail address: molikiahmedolawale@gmail.com \\ DOI: https://doi.org/10.21107/sml.v4i1.10520
}

\begin{tabular}{l} 
A RTICLE I N F O \\
\hline Keywords: \\
political party elite \\
electoral violence \\
violence-free \\
election \\
democracy \\
governance
\end{tabular}

\begin{abstract}
Failure to conduct violence-free elections in Nigeria has frequently reflected in the writings of local and foreign election observers and monitoring groups. Previous studies have devoted much attention to the consequences of electoral violence on sustenance and consolidation of democracy but less attention has been paid to the role political party elite play in this violence. This study examined the role of political party elite in election-related violence in Nigeria, 2011-2019. It equally assessed its nexus and implications for democracy and governance. The study utilized documentary research method using qualitative documentary analysis to analyze the data obtained from secondary sources following four-step approach. Findings revealed that political party elite exerted greater influence on politically-sponsored thugs, who were utilized to perpetrate election-related violence due to zerosum game, winners-takes-all syndrome, and non-punishment of electoral offenders with far-reaching implications for popular participation, free, fair and credible election, party politics, leadership legitimacy and stable polity. The study submitted that curbing party elite-sponsored electoral violence requires that the Independent National Electoral Commission (INEC) and the National Assembly wake up to their responsibility of ensuring strict enforcement of laws for electoral offences as this would deter both sponsors and perpetrators from engaging in violence during election.
\end{abstract}

Citation suggestion:

Moliki, A. O. (2021). Political party elite and election-related violence in Nigeria: The nexus and implications for democracy and governance. Simulacra, 4(1), 101-114. https://doi.org/10.21107/sml.v4i1.10520

Received 28 April 2021; Received in revised form 12 May 2021; Accepted 20 May 2021; Published online 25 June 2021. 


\section{Introduction}

Election remains an important apparatus that helps to shape peaceful transition of political regimes in every democratic state the world over. It is a mechanism through which representatives and political leaders are chosen lawfully by the people (Ashindorbe, 2018). In other words, election gives the people the power to speak through their votes. Fundamentally, elections are "regular and direct means of citizen participation in governance" (Omilusi, 2015, p. 295). Birch, Daxecker and Hoglund (2020, p. 3) described the institution of election as one that provides "a non-violent alternative to the use of force" in the acquisition of political power and which "allows citizens have greater say" over their government. Elections are critical component to the survival of democratic system, just like a human being would find it impossible to exist without the heart. This implies that election is the life-wire of democracy.

Democracy affords the citizens the opportunity to choose their political leaders freely and peacefully without threats, fear and intimidation during national, state or local elections (Adesote \& Abimbola, 2014; Ashindorbe, 2018; Ebiziem, 2015). However, elections in most democratic nations across the world in the contemporary time, are marred by violence (Besaw, 2021; FDFA Report, 2018). Election-related violence involves the premeditated or planned acts that directly or indirectly threatens election process. Political candidates and their friends, relatives and major supporters, electoral officials, electoral management body (EMB) offices and materials, election observers, party agents, media personnel, voters, and other electoral stakeholders are the main targets of electoral violence. Election-related violence involves burning of campaign vehicles, party secretariat, candidate's property, snatching of ballot boxes, physical assaults, and, possibly murder of opponents' family members or loyalists (Adesote \& Abimbola, 2014; Ashindorbe, 2018).

The electoral competitions in both developed and developing countries have become violent-ridden with records of bloodshed and wanton destruction of properties (Birch et al., 2020; Cyllah, 2014; Shenga \& Pereira, 2019). For instance, fiftyfour percent of national elections held in the world in 2020 recorded some form of violence (Besaw, 2021). Recently, postelection violence was witnessed in the United States of America (USA) after which staunch supporters of President Donald Trump on January 6, 2021 stormed US Capitol Hill in response to the allegations of election fraud in the 2020 elections. Five people were reportedly dead in the violence, while many people sustained various degrees of injuries (The Indian Express, January 9, 2021). Violence has also been part of electoral process in Asian countries, such as Afghanistan, Bangladesh, Cambodia, Nepal, Pakistan, Philippines, Thailand and East Timor (FDFA Report, 2018; United Nations Development Programme, 2011). Similar events have been experienced in sub-Saharan African countries, where episodes of electoral violence have branded their elections. From Cote d'Ivoire, Kenya, Zimbabwe, Sudan, Ethiopia, Uganda, Gambia, Mozambique to Nigeria, violence has been significant in their elections with consequences on election credibility, free choice, democratization and popular participation (Adesote \& Abimbola, 2014; Shenga \& Pereira, 2019; Straus \& Taylor, 2012).

Nigeria has conducted seventeen (17) elections in her electoral trajectory out of which the post-independent civilian and democratic governments organized seven elections, namely 1964/65, 1983, 2003, 2007, 2011, 2015 and 2019 general elections. Virtually, all these elections have been characterized by violence. Election periods 
in post-independence Nigeria have become more troubling with incidences of killing, arson, maiming, destruction of property and military coups (Adesote \& Abimbola, 2014; Bamgbose, 2012). The transition to democratic rule (Fourth Republic) on May 29, 1999 has brought with it remarkable and unimaginable trends of electoral violence. The spiralling of electoral violence during elections between 2011 and 2019 is unprecedented with the campaign periods, election days and the aftermath of declaration of election results fraught with tensions, politically motivated attacks, destruction of property, killings and violent clashes between rival political parties (Adesote \& Abimbola, 2014; Ashindorbe, 2018; Ebiziem, 2015; Nigeria Electoral Violence Report, 2011; Onimisi \& Omolegbe, 2019).

However, unhealthy rivalry, high-stake competition and 'do-or-die' politics among politicaleliteinthesocietyhavebeenidentified as contributing factors precipitating violent elections across the world, and particularly in Nigeria (Moliki, 2019; 2020a). Among the actors involved in electoral violence are political thugs/hoodlums, security agencies, militias and political party elite. Omilusi (2015, p. 295) opined that there is usually "periodic alliance between the (sic) Nigerian politicians and political thugs during electioneering" in order to manipulate the electoral process. Omilusi stated further that political gladiators across political parties, usually prepare for election in a manner that the military would have prepared for war. This is because elections are "pursued with deadly seriousness" thus making the electoral process "becoming brutal, conflictprone and violent-ridden" (Moliki, 2020a, p. 27). Moreover, election-related violence is seen as a device employed by political elite to alter, change or influence voters' behavior, voting patterns or electoral outcomes in favor of particular candidate(s) or political party (Ogundiya, 2003 cited in Inokoba \& Maliki, 2011).

Against the backdrop of the foregoing, this study is anchored on the notion that election-related violence in Nigeria is the consequent effect of zero-sum game of political party elite in a bid to manipulate the electoral process and eventually influence their outcomes, which calls for serious concerns among election stakeholders, including the academia. Although scholars in their respective studies have raised serious concerns over the violence that characterized previous elections in Nigeria (see for example, Adesote \& Abimbola, 2014; Ashindorbe, 2018; Bamgbose, 2012; Ebiziem, 2015; Nigeria Electoral Violence Report, 2011; Omilusi, 2019; Onimisi \& Omolegbe, 2019), however, none of these studies have considered interrogating the role political party elite play in this violence. This study attempts to fill this gap. The purpose of this study, therefore, is to examine the role of political party elite in election-related violence in Nigeria from 2011 to 2019.

\section{Method}

This study is aimed at interrogating the role of political party elite in electionrelated violence in Nigeria (2011-2019), their nexus and implications for democracy and governance. This study was conducted using documentary research method. To achieve this, the author sourced for information from the existing secondary sources, including published online newspapers, textbooks, magazines, journal articles, official documents from the United State Institute of Peace (USIP) and International Foundation for Electoral System (IFES), official reports from European Union Election Observation Mission (EU EOM), empirical data from Human Rights Watch (HRW), Nigeria Electoral Violence Report (NEVR) Project and 
United Nations Development Programme (UNDP), Nigeria's 1999 Constitution (as amended), 2010 Electoral Act (as amended), INEC guidelines, dissertation, thesis, online materials, and other relevant publications. Qualitative documentary analysis was adopted to analyze the collected data on political party elite and election-related violence.

Four-step approach was followed in the analysis of the data for this study. The first step was when the author gathered the relevant literature regarding the topic being studied and confirmed the authenticity of the collected documents by ensuring that their origins are reliable, genuine and sincere. This was followed by subjecting the documents to credibility test. The author checked the sources of information to guarantee that they have some level of expertise. The third step was when the author identified the themes relating to the topic being studied and utilized the parts that the findings would be representative of the larger population. The last step was to understand the significance and meaning of the collected documents in order to apply them for the purpose of achieving the objectives this study. The author applied the documents based on the themes in the study. The rationale for the selection of this research method is because the data used for this study were readily available, economical, saves time, unbiased, and useful.

\section{Results and Discussion}

\section{Political party elite and election-related violence: The nexus}

Political party elite refers to those persons with the sole and authorized power to take decisions for the party that could affect other party members. They dictate who becomes the President of a nation, vice president, senators, House of Representatives members, governors, deputy governors, state legislators, and even chairmen and councilors of local government councils, as well as those who get appointments from the government. They constitute political party executives, financiers and patrons, who anoint their stooges or godsons for choice of political posts, support them and, perhaps, sponsor them in order to get to their political destinations (Moliki, 2019). Political party elite include those registered party members, who hold the larger shares of party financing and may occupy important positions in political parties at the national, state or local government levels. They also include persons of great political power and prestige with large number of followers. They are a minority, yet monopolize power within the party, and by extension, the nation.

Political parties have become arenas where do-or-die politics is played and electoral rules are blatantly violated leading to tensed political atmosphere, breakdown of law and order and an undermined level-playing field for political candidates (Elaigwu, cited in Albert, 2003; Moliki, 2019). The current political parties are a collection of people with diverse interests. Nigeria's political parties have been characterized by factionalism, division and inter and intraparty squabbles of different dimensions, due to dearth of viable political ideology and workable internal democracy. Lack of internal democratic practices has made political parties not to abide by the basic rules and guidelines related to democratic election (Moliki, 2019; 2020b).

In the last two decades, competing for popular support and political power among political parties in both the developed and developing countries has become a contentious task that has revolved around force, threats, intimidation and violence. Chaturvedi (2005, p. 189) in his study of political parties in developing countries, concluded that the motive of perpetrating 
violence is to rig election. He argued further that political party with lower political support would resort to violence. In other words, the lower the political support base of a political party, the higher its involvement in violence. Such political party would use violence to force other competing groups or electorate to vote in its favor or restrain them from voting. As such, election-related violence is mostly carried out by recruited political thugs or party militias, who might have been reared, groomed and sponsored by party leaders and/or candidates for the purpose of harassing, assaulting and intimidating their rivals and members of the public in order to rig elections.

Moliki (2019) pointed out that political elite utilize political party platforms to capture power through electoral process that are often marred by irregularities and violence with the belief that that will enable them to engage in primitive accumulation of public wealth. The struggle to win state power and control its resources at all costs is the root of violence associated with elections in Nigeria. Similarly, Human Rights Watch's report (2019) maintained that voter intimidation and violence, for instance, during the 2019 general elections were perpetrated by armed men and criminal elements hired by political party candidates to disrupt the voting process. The leadership of political parties during elections work in rivalry to one another and engage in antidemocratic practices to outwit one another in their bid to manipulate the process and secure or retain political power.

Political party elite constitute significant political actor that determine the directions of election. Extant research has revealed that political party elite during elections encourage conflict and violence to disrupt campaigns, intimidate voters, and influence the timing or election results (Ndulo \& Lulo, 2010, cited in Omilusi, 2015). Moreover, it is common that political thugs are contracted by political party elite to unleash terror on their opponents, particularly those perceived to be a threat to their victory at the polls, and to destroy and snatch ballot boxes on the election day. Security officials are also contracted to harass, arrest, forcefully disperse, shoot, wound or kill the people (Ladan-Baki, 2016). This is why during contemporary national and state elections, candidates from different political parties are requested to sign peace accords in order to mitigate election-related violence and encourage issue-based campaign, refrain from using inflammatory languages, and enjoin party supporters to refrain from violent conduct that could jeopardize the credibility of election.

In spite of this measure, there have emerged cases of clashes between party supporters during party primaries, election campaign periods, voting days and after the declaration of election results. For instance, Moliki (2019) documented violent clashes among party elite-controlled factions within the All Progressives Congress (APC) and People's Democratic Party (PDP) in Ogun State, which invariably resulted in parallel congresses in both political parties with two executive councils produced from the ward to the state levels. The tussles were linked to power blocs that anointed candidates for the 2015 general elections. The escalation of the crises also impacted negatively on political stability in Ogun State. Inter-party crises or rivalries have also induced electoral violence in Nigeria.

One notable inter-party crisis in Nigeria was that of pre and post-election clashes between Congress for Progressive Change (CPC) and People's Democratic Party (PDP) in the northern states of Katsina, Kano, Kaduna, Bauchi, Adamawa, Gombe and Taraba, and South-South state of Akwa Ibom, in the aftermath of the 2011 Presidential election. In the case of preelectoral violence in Akwa Ibom State, which 
occurred on March 22, 2011, Police report officially confirmed that two supporters of the People's Democratic Party (PDP), Etop Nicholas Idiong (a trader) and Daniel Udo Akpan (a commercial motorcyclist), were brutally murdered in Ikot Ekpene (cited in Adesote \& Abimbola, 2014, p. 146). Several other properties were lost to the violence as the report revealed as below:

Two hundreds brand new Peugeot 307 cars, 500 brand new tricycles, the Goodluck/Sambo Campaign office which was burnt down by the rampaging mob, Fortune International High School owned by Senator Aloysius Etok which was razed down with school children in session and over 20 Toyota Hiace buses belonging to the PDP and Godswill 2011 Campaign Organization, and nine Hilux Jeeps belonging to the Government of Akwa Ibom State which were either completely destroyed or vandalized (Official Gazette of Government of Akwa Ibom State, 2012, cited in Adesote \& Abimbola, 2014, p. 146).

Moreover, there were records of interparty clashes between All Progressives Congress (APC) and People's Democratic Party (PDP) in Lagos and Rivers states, respectively, during the 2015 general elections. The precipitating factors for the clashes were inter-party rivalries.

Imposition of candidates by party leadership is also a precipitating factor to election-related violence. Imposition of candidates has been a feature of Nigerian politics since the inception of party politics in 1920s. Most crises that bedeviled party primaries and general elections were the consequences of imposition of candidates. Oftentimes, political parties do not present the candidates selected by party members for elections, rather party leaders and executives impose their stooges at the detriment of competent and qualified candidates. It was reported that crisis that erupted in People's Democratic Party (PDP) in Osun State during the 2011 governorship election was succession crisis on who was to become the governor after Olagunsoye Oyinlola; the imposition of Senator Iyiola Omisore festered serious crisis that polarized the party into different factions. Omisore was imposed by the People's Democratic Party (PDP) national leadership as the governorship flagbearer in the April 2015 governorship election thereby leading to violence among party stalwarts and their supporters in Osun State preparatory to the election (Salaudeen, 2016 cited in Moliki, 2020b, p. 114).

Party elite use different strategies, including hate speech, to achieve electoral success, which often culminates in preelectoral violence. During electioneering campaigns, political rallies and parades in the build up to 2015 and 2019 general elections, political elite from different political parties employed hate speeches and various propaganda tools to project the programmes of the parties and their candidates to their supporters while destroying the images of political opponents and inciting their supporters to violence. For instance, Ezeibe (2015) in his critical analysis of the effect of hate speech on electoral violence in Nigeria from 2010 to 2015, argued that political leaders across political parties were involved in the use of hate speeches to score cheap political points during electioneering campaigns and this has accounted for the escalation of election-related violence in Nigeria.

There were many instances where political party elite incite violence with their utterances on the media or campaign grounds. Prior to the 2011 general elections, Shehu Sani, a member of Congress for Progressive Change (CPC) in 2010 said that, "President Goodluck Jonathan should not contemplate contesting the 2011 presidential election. Any attempt by him to contest amounts to incitement and a recipe for political instability" (cited in 
Ezeibe, 2015, p. 15). Another statement was credited to the then Presidential candidate of Congress for Progressive Change (CPC), General Muhammadu Buhari, after the 2011 elections thus: "If what happened in 2011 should again happen in 2015, by the grace of God, the dog and the baboon would all be soaked in blood" (Binniyat, Vanguard, May 15, 2012 cited in Ezeibe, 2015, p. 16). In the build-up to the 2015 general elections, former Governor of Ekiti State, Peter Ayo Fayose, was reported to have said: "Buhari would likely die in office if elected, recall that Murtala Muhammed, Sani Abacha and Umaru Yar'Adua, all former heads of state from the Northwest like Buhari, had died in office" (ThisDay, January 19, 2015 cited in Ezeibe, 2015, p. 18). These, among other unguided statements, had once ignited violence before, during and after elections in Nigeria. Ezeibe (2015, p. 19) posited that hate speeches among northern elite in 2010 "led to the post-2011 election violence in Nigeria." Onimisi and Omolegbe (2019) observed that the level of inflammatory campaigns carried out across political divide by political elite, political thugs and loyalists before the 2019 general elections led to the number of violence experienced in some parts of the country.

However, the reasons for the deleterious trends of election-related violence by politically-sponsored thugs are not farfetched due to do-or-die affair of electoral contest, zero-sum game and winners-takesall syndrome of Nigerian politics. Alemika (2011), while examining the emerging trend and lessons on post-election violence in Nigeria agreed with the view of the Electoral Reform Committee Report (2008, p. 19) that "politicians, in Nigeria, have over the years become more desperate and daring in taking and retaining power; more reckless and greedy in their use and abuse of power; and more intolerant of opposition, criticism and efforts at replacing them". The implication of the above is that politics has become a 'door-die' affair with politicians going to any length at achieving their desired political goals, hence defections and intra-party conflicts become institutionalized leading to electoral violence. In its description of the nature of electoral contests in Nigeria, Transition Monitoring Group (2004, cited in Omilusi, 2015, p. 296) aptly summarized as follows: "electoral contests are seen as a door-die affair, where contestants employ fair and foul means to win, (and) results declared in those situations are hardly acceptable to the opposition."

Ashindorbe (2018) questioned the inherentzero-sum and winner-take-all nature of electoral contest, as well as promotion of sectional and narrow interests by political leaders in Nigeria. He commented by saying that the situation may be difficult to eradicate because "having access to political offices not only allow the political elite to perpetuate themselves against the democratic wishes of the people, but also enable them to dole out state resources in a clientelistic network of patronages and corruption." Corroborating this submission, former President Jonathan at the signing of a peace accord during the 2015 general election, who was quoted to have said that, "the winner-takes-all is the problem" but suggested that if the party that wins at the polls could form government by making the opposition political parties part of its cabinet, there is likelihood that politicians will play by the rule and abide by the legal frameworks that guides the conduct of election (Osuntokun, 2015 cited in Ashindorbe, 2018, p. 94).

Poor implementation of electoral regulatory laws on punishment of electoral offenders has also been identified as a precipitating factor for electoral violence. The Constitution of the Federal Republic of Nigeria (CFRN), 1999 (as amended) and the Electoral Act, 2010 (as amended) serves as the legal frameworks regulating the 
activities of political parties in Nigeria. These legal instruments empower the Independent National Electoral Commission (INEC) and the National Assembly to regulate the role of electoral stakeholders in the electoral process. For instance, section 227 of CFRN 1999 (as amended) provides that:

No association shall retain, organize, train or equip any person or group of persons for the purpose of enabling them to be employed for the use or display of physical force or coercion in promoting any political objective or interest or in such manner as to arouse reasonable apprehension that they are organized and trained or equipped for that purpose.

Section 228 of the Constitution empowers the National Assembly to make provisions for the punishment of any person who contravenes the above provision. Section 81 of the Electoral Act, 2010 (as amended) states the penalty for contravening the above section of the Constitution, which prohibits maintaining quasi-military group(s). The section provides for fines of “(a) $₫ 500,000.00$ for the first offence; (b) $\underline{\mathbb{N} 700,000.00}$ for any

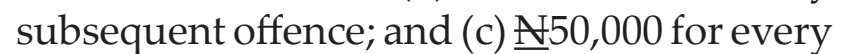
day that the offence continues for political parties", while for individual persons (such as political party elite, candidates) or group of individuals (such as political group, bloc or association), the punishment stipulated

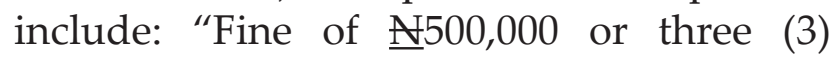
years imprisonment or both." Section 95 of the Electoral Act 2010 (as amended) spells out the punishment for "using abusive, slanderous, provocative language during campaigns" by political party, candidate or any other individual person to cover the "maximum fine of $\underline{\mathbb{N} 1,000,000}$ or 12 months' imprisonment" for individuals, and "fine of $\underline{\mathbb{N} 2,000,000}$ in the first instance,

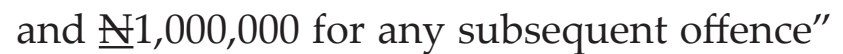
for political parties. Section 96, on the other hand, identifies the punishment for "directly or indirectly threatening a person with the use of force or violence during any political campaign to compel support to or refrain from supporting a political party or candidate" to include a fine of "maximum

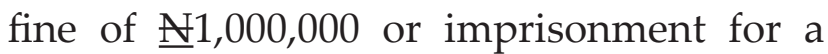
term of 12 months" for individual, and "fine of $\underline{\mathbb{N} 2,000,000}$ in the first instance, and \#500,000 for any subsequent offence" for political parties (Policy and Legal Advocacy Centre, 2019, pp. 23-25).

In spite of the above provisions, Nkwede (2016, p. 17) claimed that INEC lack political will and is "technically incapacitated to arrest and prosecute electoral offenders". Consequently, perpetrators of electoral violence go scot-free and in cases where they are arrested, they are subsequently discharged and told to "go and sin no more". The sponsors are political elite, who are untouchable and due to their socio-political status, are above the law. Human Rights Watch (2007) states that the sponsors and perpetrators of election-related violence generally enjoys complete impunity because of the powers of incumbency and the tacit approvals by the power that be. If these challenges militating against Nigeria's electoral process are not curtailed in due time, it would have adverse effects on sustainability and consolidation of her democracy.

\section{Implications of party elite-sponsored electoral violence for democracy and governance}

One major implication of party elitesponsored violence is that it poses a threat to sustainability and consolidation of Nigeria's democracy. Election and political party are twin elements that make democracy unique and acceptable form of government across the world. If any or both are threatened, democracy is also endangered. Flawed and rigged elections, inter and intra-party 
conflicts and attendant violence, including arson, maiming, looting, killing and wanton destruction of property (Adesote \& Abimbola, 2014) led to the collapse of the first and second republics. Ashindorbe (2018) also accounted for electoral violence in Nigeria's political history, which contributed to the truncation of previous attempts at entrenching democracy in Nigeria by the military juntas. The prevalence of electionrelated violence since the return to democracy in May 29, 1999, and particularly in the 2011, 2015 and 2019 general elections, could ruin the actualisation of democratic consolidation project in the current Fourth Republic. This has been established in the work of Ebiziem (2015), who opined that electoral violence is a threat to democracy.

Popular participation is threatened if election is often violent and by consequence, voter apathy takes its place. Moliki and Dauda (2014) defined voter apathy as a subset of political apathy, which brings about indifferent or decline in the involvement of potential voters in the country's electoral process due to certain factors that could mar their participation. Voter apathy could be in form of refusal to register during voter's registration exercise or to vote during election, and failure to protest against rigging or ballot snatching, and to assist the security agents with useful information (Yakubu, 2012, cited in Moliki \& Dauda, 2014, p. 205). However, election involves participation of the people in the act of choosing their leaders that are capable of serving their interests in governance. It occasions significant changes in the allocation of power to the few political leaders, who rule on behalf of the majority in any given state.

Scholars have, however, advanced that election-related violence could lead to apathy (Ashindorbe, 2018; Bamgbose, 2012; Inokoba \& Maliki, 2011; Kolawale, Abubakar, Owonibi \& Adebayo, 2012; Moliki, 2018). In a study carried out on causes and effects of political apathy on the electoral process during the 2014 Ekiti governorship election, it was established that violence before, during and after election has negative impact on political participation of the people. Due to the belief that "since politics is violence-prone, their involvement in the process may lead to loss of their lives and/ or properties" and prospective voters may also stay away from polling centres (Moliki \& Dauda, 2014). This is corroborated in the view of Ashindorbe (2018), who stated that indifference and apathy on the part of voters during election is the fallout of pre-electoral violence.

Some voters often perceive the election day as a battlefield, with the fear that the process may be violently and abruptly disrupted by political thugs leading to their death. The inter-party clashes between All Progressives Congress (APC) and People's Democratic Party (PDP) in Edo, Lagos, Ogun and Rivers states in 2015 have also led to intimidation, tension, loss of lives, and voter apathy (Moliki, 2018). A similar sentiment was shared by Inokoba and Maliki (2011, p. 23), who noted that electoral violence "has encouraged political apathy and indifference of the citizenry." Toeing the same line of thought, Bamgbose (2012) argued that the electorate were scared to participate in 2011 elections due to associated pre-electoral violence. In their analysis of gender role in party politics in Nigeria, Kolawale, et al. (2012) stated that violence before, during and after elections and the attendant insecurity that often characterized Nigeria's elections has hindered active women's participation in Nigerian politics. Whereas popular political participation is the bedrock of democracy, voters' apathy during the electoral process is a threat to Nigeria's democracy.

Violence and election rigging are intertwined. Violence is mostly utilized by political actors to execute election rigging while most election-day and post-election 
violence is the fallout of blatant election rigging. For instance, the crisis that triggered post-election violence in Bauchi State in April 2011 was due to the alleged rigging and manipulation of election results. The Nigeria Electoral Violence Report (NEVR) Project (2011) reported the "incidents of political thuggery, politically-motivated assassinations, intimidation of opponents and outright rigging" (p. 16) during the 2011 gubernatorial, National Assembly and State Assembly elections. The crises that occurred in Rivers State during the 2015 general elections was due to the alleged manipulation of election results, inter-party rivalry, ballot snatching and failure of card readers. Similarly, the inter-party clashes reported in Edo and Ogun states between All Progressives Congress (APC) and People's Democratic Party (PDP) in 2015 was due to ballot snatching and result manipulation. Moreover, inter-party clash in Ogun State between People's Democratic Party (PDP) and All Progressives Congress (APC) in 2015 was due to alleged inducement of opposition party members by ruling party agents in Obafemi Owode Local Government Area as well as irregularities experienced in other local government areas (Moliki, 2018).

Election-related violence has resulted in not only manipulation and ballot snatching, but also disruption of electoral exercise, which has negatively affected the election outcome. Election as a substratum of democracy serves the purpose of peaceful change in government (Ashindorbe, 2018). The whole concept of an orderly process of leadership succession and changes which election guarantee makes it unique and one of the most important ingredients of liberal democracy (Momoh \& Adejumobi, 1999). In the process of acquiring political powers or transiting from one government to the other, free, fair and violence-free elections cannot be underestimated. Violence negates the conduct of peaceful election. Electoral violence is considered one of the political strategies adopted by political elite to manipulate and influence the outcome of an election in their favor. The ruling party resort to violence once it is perceived that there is the possibility of losing the election to the opposition party. However, subverting the will of the people through violence is a threat to democratic consolidation in Nigeria.

Electoral violence is an anathema against virile party politics. Ordinarily, in the modern sense, politics is equated with party politics. Political party remains one of the basic indispensable institutions of democracy that provides a structure for political participation. Electoral violence weakens political party and could precipitate formation of new weak political parties. Violent clashes between political parties results from "clash of political interest" (Moliki, 2018).

Electoral violence also questions the legitimacy of returning candidates. Peaceful election serves as an instrument of legitimization for the state and those who manage the reins of that state. The conduct of violent elections in Nigeria since 1999 has generated legitimacy crisis. In a situation where the selection of candidates or party primaries is inherently flawed and do not reflect the true choice and will of the people, the government formed on this basis may not be accepted by the people (Ashindorbe, 2018). A violence-free election gives the government the right to command and receive obedience from citizens and such government is vested with authority to rule. In other words, when a body of voters chose their leaders in an election devoid of rancor and violence, it tends to reflect the wishes of the people and as such gain their consent to rule on their behalf. However, if political leaders are elected through rigged and violent election, they forfeit legitimacy and are consequently disconnected from the people. 
Furthermore, in the final analysis, widespread violence associated with election overheats the polity. A violent-prone election threatens political stability. Studies, among which are Adesote and Abimbola (2014), have argued that elections characterized by violence remain a major source of political instability in a democratic Nigeria. The unprecedented magnitude that the election periods have assumed had resulted in loss of lives, wanton destruction of property and displacement of populations. Aljazeera News (April, 2011, p. 20) reported that "more than 200 people" were killed and "an estimated 40,000 others were displaced" during the violence triggered after the declaration of President Goodluck Jonathan as the winner of the April 2011 Presidential election by INEC. The pronouncement brought about disorder that rocked several parts of the country leading to destruction of property, burning of houses, vehicles and election materials, murder, clashes between rival political parties, physical harm and intimidation. Similar situation was experienced during the 2015 and 2019 general elections but with minimal cases of pre, during and postelectoral violence.

\section{Conclusion}

Electoral violence has become a cankerworm that has eaten deep into Nigeria's electoral system. This explains why none of the previous elections could be free from violence. This situation is due to desperation of political party elite to win election at all costs thereby intensifying unhealthy electoral competition coupled with zero-sum character and winnertakes-all syndrome of politicians, hence it may be difficult if not impossible to conduct election devoid of violence due to numerous vested interests in the political space jostling to retain power or acquire it by all means necessary without taking into consideration the consequence on popular participation, credible election, sustainable democracy, political stability and the global image of Nigeria as a democratic state. However, conducting violence-free election is achievable if and only political party elite and other political actors could play politics in accordance with the rule of the game and allow electoral contests to be guided by constitution, electoral laws, and the guidelines of their various political parties.

In view of the foregoing, the study recommends that the Independent National Electoral Commission (INEC) and the National Assembly should wake up to their responsibilities of enforcing the rules that guide the conduct of election in Nigeria. It should intensify efforts at monitoring the activities of political parties throughout electoral cycles. Secondly, there should be strict enforcement of electoral laws on those using direct or indirect threat of use of force or violence during the electoral process. When this measure is strictly implemented, the sponsors (political party elite) and perpetrators (political thugs/militias) would be deterred from engaging in violence during election.

Moreover, there is the urgent need to overhaul the INEC in order to make it independent of politicians and the ruling government. An independent agency should be created to oversee the enforcement of penalties for contravening sections 227228 of CFRN 1999 and sections 81, 95-96 of Electoral Act 2010. Furthermore, the National Assembly should deem it fit to carry out its oversight functions for which its members were elected for. They should stop playing politics with enacting provisions for the punishment of any person who contravenes the provisions of the Nigeria's Constitution and Electoral Act. Above all, political offices should be made less lucrative 
by subjecting the holders to critical scrutiny. Political leaders should see their election as opportunity to serve the people and not to engage in primitive accumulation of public wealth.

\section{Acknowledgement}

The author appreciates the painstaking review of Dr A. A. Adenuga, and the two anonymous reviewers of Simulacra, and $\mathrm{Mr}$ Kazeem Dauda, for his unalloyed support during the compilation of this study.

\section{Declaration of Ownership}

This study is my original work. It has not been submitted for consideration or published elsewhere.

\section{Conflict of Interest}

There is no conflict of interest to declare in this study.

\section{Ethical Clearance}

This study was approved by the institution.

\section{References}

Adesote, A.S., \& Abimbola, J.O. (2014). Electoral violence and the survival of democracy in Nigeria's fourth republic: A historical perspective. Canadian Social Science, 10(3), 140-148. DOI: https://doi. org/10.3968/4593

Alemika, E.E.O. (2011). Post-election violence in Nigeria: Emerging trend and lessons. CLEEN Foundation Publication.

Aljazeera News. (2011, April 20). Hundreds dead in Nigeria post-poll violence. https:// www.aljazeera.com/news/2011/4/20/ hundreds-dead-in-nigeria-post-pollviolence
Ashindorbe, K. (2018). Electoral violence and the challenge of democratic consolidation in Nigeria. India Quarterly, 74(1), 92-105. DOI: https://doi. org/10.1177/0974928417749639

Bamgbose, J.A. (2012). Electoral violence and Nigeria's 2011 general elections. International Review of Social Sciences and Humanities, 4(1) 205-219.

Bekoe, D. (2011). Nigeria's 2011 elections: Best run, but most violent. Peace Brief 103. August 15. United State Institute of Peace (USIP).

Besaw, C. (2021, February 18). Election violence spiked worldwide in 2020-Will this year be better? The Conversation. https://theconversation.com/electionviolence-spiked-worldwide-in-2020will-this-year-be-better-153975

Birch, S., Daxecker, U., \& Hoglund, K. (2020). Electoral violence: An introduction. Journal of Peace Research, 57(1), 3-14. DOI: https://doi. org/10.1177/0022343319889657 journals. sagepub.com/home/jpr

Chaturvedi, A. (2005). Rigging elections with violence. Public Choice, 125, 189-202. DOI: https://doi.org/10.1007/s11127-005-34156

Cyllah, A. (2014). Election worth dying for? A selection of case studies from Africa. International Foundation for Electoral System (IFES).

Ebiziem, J.E. (2015). Electoral violence and sustenance of democracy in Nigeria: A critical appraisal of 2015 presidential election. Journal of Political Science and Leadership Research, 1(8), 37-51.

European Union Election Observation Mission [EU EOM]. (2019). General elections 2019. Second preliminary statement. EU EOM Publication.

Ezeibe, C.C. (2015). Hate speech and electoral violence in Nigeria. Paper presented at a Two-day National Conference on The 
2015 General Elections in Nigeria: The Real Issues organized by The Electoral Institute, Abuja, held at The Electoral Institute Complex, INEC Annex, Abuja, 27-28 July.

FDFA Report. (2018). Promoting peace and democracy in the context of elections - FDFA. https://www. swisspeace.ch/apropos/friedens-unddemokratiefoerderung-im-kontext-vonwahlen-eda

Human Rights Watch [HRW]. (2019, June 10). Nigeria: Widespread violence ushers in President's new term; Investigate attacks, ensure justice. https://www.hrw.org/ news/2019/06/10/nigeria-widespreadviolence-ushers-presidents-new-term

Inokoba, P.K., \& Maliki, A.E. (2011). Youths, electoral violence and democratic consolidation in Nigeria: The Bayelsa state experience. Anthropologist, 13(3), 217-225.

Kolawale, T.O., Abubakar, M.B., Owonibi, E., \& Adebayo, A.A. (2012). Gender and party politics in Africa with reference to Nigeria. Online Journal of Education Research, 1(7), 132-144.

Ladan-Baki, I.S. (2016). Electoral violence and 2015 general elections in Nigeria. Global Journal of Human-Social Science, 16(1), 23-30.

Moliki, A.O. (2020a). Intra-party crises, defections and electoral performance in 2015 General Elections in Kwara State, Nigeria. KIU Journal of Social Sciences, 6(2), 27-37.

Moliki, A.O. (2020b). Party leadership, intraparty crisis and democratic consolidation in Southwest Nigeria. Islamic University Multidisciplinary Journal (IUMJ), 7(2), 105-117.

Moliki, A.O. (2019). Intra-party conflict, party defections and political stability in Ogun State, 2013-2018. Hyuku Journal of Politics and Development Studies, 4(1), $1-13$.
Moliki, A.O. (2018). Party conflict, defection and performance in Nigeria's 2011 and 2015 general elections in Ogun and Kwara states. An unpublished Ph.D Thesis, Department of Political Science and Public Administration, Babcock University, Ilishan-Remo, Ogun State.

Moliki, A.O., \& Dauda, K.O. (2014). Political apathy, electoral process and Nigeria's democracy: A study of 2014 Ekiti Governorship Election. Journal of Applied Education and Vocational Research (JAEVR), 12(1), 200-217.

Momoh, A, \& Adejumobi, S. (1999). The Nigerian military and the crisis of democratic transition. Civil Liberties Organization.

Nigeria Electoral Violence Report (NEVR) Project. (2011). Final Report on Nigeria's April 2011 National Elections. Project executed by the National Association for Peaceful Elections in Nigeria (NAPEN) with support from the International Foundation for Electoral Systems (IFES)/ USAID.

Nkwede, J.O. (2016). Electoral violence and 2015 general elections in Nigeria: A focus on the ramifications of political developments in Ebonyi State. Developing Country Studies, 6(9), 9-18.

Omilusi, M.O. (2015). Electoral violence in Nigeria: The unwritten pact between political elites and political thugs. International Journal in Management and Social Science, 3(10), 295-307.

Onimisi, T., \& Omolegbe, L.T. (2019). Appraisal of the 2019 post-electoral violence in Nigeria. Malaysian Journal of Social Sciences and Humanities, 4(3), 107113.

Policy and Legal Advocacy Centre. (2019). Electoral act and INEC guidelines simplified. Policy and Legal Advocacy Centre (PLAC).

Shenga, C., \& Pereira, A. (2019). The effect of electoral violence on electoral participation in Africa. Cadernos de 
Estudos Africanos, 38, 1-18. DOI: https:// doi.org/10.4000/cea.4459

Straus, S., \& Taylor, C. (2012). Democratisation and electoral violence in sub-Saharan Africa, 1990-2008. In D. A Bekoe (Ed.), Voting in fear: Electoral violence in subSaharan Africa (pp. 15-38). USIP Press.

The Indian Express. (2021, January 9). US Capitol Hill siege highlights: Another police officer succumbs to injuries sustained during Capitol storming. https://indianexpress.com/study/ world/us-electoral-college-meet-liveupdates-capitol-locked-down-as-trumpprotesters-clash-with-police-7135853

United Nations Development Programme [UNDP]. (2011). Understanding electoral violence in Asia. UNDP. 